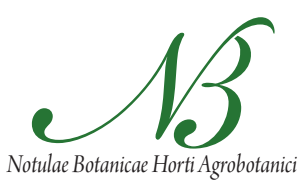

Cluj-Napoca

\title{
Foliar Application of Potassium Nitrate Affects the Growth and Nitrate Reductase Activity in Sunflower and Safflower Leaves under Salinity
}

\author{
Nusrat JABEEN*, Rafiq AHMAD \\ University of Karachi, Department of Botany, Biosaline Research Laboratory, \\ Karachi,Pakistan; jabeennusrat@yahoo.com (*correspondingauthor)
}

\begin{abstract}
Effect of foliar application of $\mathrm{KNO}_{3}$ on growth and the activity of nitrate reductase were studied in the leaves of sunflower (Helianthus annuus L.) and safflower (Carthamus tinctorius L.) plants growing under different levels of salinity. The seeds were sown in pots under non saline condition and saline water irrigation was started at three leaf stage after germination. Different concentration of saline water (i.e. $0.3 \%$ and $0.6 \%$, equivalent to an EC of 4.8 and $8.6 \mathrm{dS} / \mathrm{m}$ respectively) were made by dissolving sea salt per litre of tap water. Nutrient solution of $\mathrm{KNO}_{3}$ was sprayed at the rate of $250 \mathrm{ppm}$. The concentration of $\mathrm{Na}^{+}$and $\mathrm{Cl}^{-}$rapidly increased in the leaves of both the plants under salinity stress. In contrast the nitrate $\left(\mathrm{NO}_{3}{ }^{-}\right)$and soluble protein concentration were decreased with the increasing salinity. Salinity reduced leaf area, its fresh and dry weight per plant and also inhibited the activity of Nitrate reductase (NRA) enzyme. The application of $\mathrm{KNO}_{3}$ significantly reduced the increasing tendency of $\mathrm{Na}^{+}$and $\mathrm{Cl}^{-}$and increased leaf area, its fresh and dry weight per plant, $\mathrm{NO}_{3}$ and soluble protein concentration and NR activity in leaves irrespective to the growth of plant under non saline or saline conditions.
\end{abstract}

Keywords: foliar spray, growth, nutrient solution, nitrate reduction, salinity stress

\section{Introduction}

The availability of good quality water is one of the major limiting factors for plant growth as irrigation water may often contain salts and ions that can have negative impacts on the plant growth and development. Salt water in the root zone induces osmotic changes and directly affect nutrient uptake as $\mathrm{Na}^{+}$reducing $\mathrm{K}^{+}$uptake or by $\mathrm{Cl}^{-}$reducing $\mathrm{NO}_{3}^{-}$uptake (Cornillon and Palloix, 1997; Halperin et al., 2003). Besides limiting the acquisition of nitrate by roots salinity may also restrict the ability of plants to reduce and assimilate nitrogen $(\mathrm{N})$, as a result of the inhibition of the activity of enzymes involved in $\mathrm{N}$ metabolism. The cytosolic NADH nitrate reductase (NR; EC 1.6.6.6), the first enzyme in the pathway of nitrate assimilation (Flores et al., 2002), is one of the enzymes whose activity has been shown to decline in salt stressed leaves of various plant species, including Sorghum vulgare (Rao and Ganaham, 1990), bean and cotton (Gouia et al., 1994), maize (AbdEl Baki et al., 2000), Prosopis alba (Meloni et al., 2004), sunflower (Azedo-Silva et al., 2004) and tomato (Debouba et al., 2007). The information regarding the effect of salinity on $\mathrm{N}$ uptake and assimilation are limited and controversial (Viegas et al., 1999). Stimulation in nitrate reductase activity (NRA) has been reported in Phaseolus aureus (Misra and Dwiverdi, 1990) and in annual ryegrass (Sagi et al., 1997) under salt stress condition. These contradictory results highlight the need to pursue the investigation on the effects of salt stress on leaves NR activity, extending these studies to a wider number of species.
Nitrates is one of the major sources of $\mathrm{N}$, taken up by roots of higher plant, translocate to the shoot, store in vacuole and assimilate into reduced $\mathrm{N}$ products. The processes of nitrate uptake, translocation, and assimilation are interdependent and closely regulated in higher plants (Huber et al., 1996; Sivasankar and Oaks, 1996). An increase in the amount and activity of nitrate reductase leads to a corresponding increase in the potential for nitrate reduction and confers a greater capacity for amino acid synthesis, protein synthesis, or total $\mathrm{N}$ assimilation (Barneix and Causin, 1996; Lopez-Cantarero et al., 1997). Nitrate availability, growth regulators, light, and other physiological and environmental parameter are the factors which effect the regulation of nitrate assimilation (Crawford 1995; Lillo, 1994; Ruiz et al., 1998). Nitrate uptake and transport appear sensitive to salinity and modification in nutrient supply can alleviate the negative effect of salinity. It is well known that exogenous application of $\mathrm{NO}_{3}$ may increase the nitrate content of salt stressed plant and improves the tolerance of plant to salinity to various extents (Ebert et al., 2002; Kaya and Higgs, 2003). Foliar application of $\mathrm{KNO}_{3}$ was found to increase nitrate content of ryegrass leaves under non-saline or saline condition (Tabatabaei and Fakhrzad, 2008) and NR activity and protein content in tomato and maize (Maritinez and Cerda ,1989; Panday, 2000).

In the present study, the effect of foliar application of $\mathrm{KNO}_{3}$ was assessed on growth, amount of nitrate, its reduction and assimilation in the leaves of sunflower and safflower subjected to different levels of salinity. 


\section{Materials and methods}

\section{Plant material and culture conditions}

A moderately salt tolerant variety of sunflower ( $\mathrm{He}$ lianthus annuus L. cv 'NuSun 636') and safflower (Carthamus tinctorius L. cv 'Spiny 321') were sown in plastic pot. These pots were $0.28 \mathrm{~m}$ in diameter, and $0.30 \mathrm{~m}$ deep, having basal holes for leaching irrigation water, filled with $20 \mathrm{~kg}$ of sandy loam and cow dung manure (9:1) having $\mathrm{pH} 7.4 \mathrm{dS} / \mathrm{m}$. The air temperature and relative humidity throughout the growing period was $25-32^{\circ} \mathrm{C}$ and $60-80 \%$ respectively. Nitrogen, Phosphorous, Potassium (NPK) ratio in fertilizer was given 4:3:2 through urea, diammonium phosphate (DAP) and sulphates of potash (SOP) for sunflower as recommended by Nawaz et al. (2003), which amounts to $0.744 \mathrm{~g}$ Nitrogen (N), $0.558 \mathrm{~g}$ Phosphorus (P) and $0.372 \mathrm{~g}$ Potassium $(\mathrm{K})$ per pot, and 7:15:7 for safflower as recommended by Naik et al. (2007), which amounts to $0.217 \mathrm{~g}(\mathrm{~N}), 0.465 \mathrm{~g}$ Phosphorus $(\mathrm{P})$ and $0.217 \mathrm{~g}$ Potassium $(\mathrm{K})$ per pot, given at the time of sowing and at the time of flowering. A certain amount of micronutrients were given in soil vide Hoagland solution (Hoagland and Arnon, 1938) twice along with irrigation water.

It has been conducted two separate experiments for sunflower and safflower in November 2008 in a randomized complete block design with five replications. 30 pots, of each experiment, were divided in 02 sets comprising of 15 pots each. One set was of control (non spray) and other set was treated with $\mathrm{KNO}_{3}$. Out of 15 pots of each set, 5 pots of each were subjected to following different levels of saline water irrigation.
a) Non saline water (control)
b) $0.3 \%$ sea salt solution*
$(\mathrm{EC} 0.5 \mathrm{dS} / \mathrm{m})$
$($ EC $4.8 \mathrm{dS} / \mathrm{m})$
c) $0.6 \%$ sea salt solution
(EC $8.6 \mathrm{dS} / \mathrm{m})$

The seeds were sown in pots under non saline condition and saline water irrigation was started at three leaf stage after germination to get seedlings of equal size. After thinning only one seedling was kept in each pot for further work. They were irrigated with gradual increasing sea salt concentration weekly up to reaching the desired salinity levels of the experiment mentioned above. To maintain the required soil medium salt levels the EC of the soil medium was measured periodically by portable EC meter. Plants were sprayed with nutrient solution of $\mathrm{KNO}_{3}$ at the time of seedlings establishment, grand period of growth and incipient of floral heads at the rate of $250 \mathrm{ppm}$. The calculated amount of $\mathrm{K}^{+}$and $\mathrm{NO}_{3}^{-}$in their respective solution, applied to the plants through foliar application was $96.5 \mathrm{ppm}$, and $153.5 \mathrm{ppm}$ respectively. Tween-20 (0.1\%) was used as a wetting agent for each treatment. A volume $300 \mathrm{ml} /$ plant, of the solution was sprayed on all pots with a manual sprayer. Spray was carried out between 09:00 and 11:00 AM. The plants were sprayed with solutions with uniform coverage until the leaves were completely wet and the solution ran off the leaves. At the time of spray other plants were covered with plastic sheet to prevent the contamination of sprayed nutrients. Control (non saline) plants were irrigated with 3.51 of tap water and plants under saline treatments were irrigated with 3.51 of their respective sea salt solution ensuring about $40 \%$ leaching.

\section{Plant sampling and analysis}

Leaves were sampled at flowering stage. Leaf samples were standardized by using only plants with the same size of fully expanded leaves almost from the middle part of each replicate plant. The material was rinsed with distilled water. Fresh leaf matter was used for NRA assay, proteins and nitrate analysis. A subsample was prepared for $\mathrm{Na}$ and K analysis according to Chapman and Pratt (1982), where the weighed plant sample were dry ashed in Muffle furnace at $550^{\circ} \mathrm{C}$, then extracted by $2 \mathrm{~N} \mathrm{HCl}$. Total $\mathrm{Na}$ and $\mathrm{K}$ content were determined through flame photometer (JENWAY PFP7). Chloride in samples was extracted in deionized distilled water and determined with a chloride analyzer (Corning, 925).

\section{Measurement of vegetative characteristics}

Leaf area, fresh and dry weight of leaves per plant was measured at the grand period of growth. Leaf area was measured with the apparatus AM-Licor 1300 (Lincoln, Nebraska, USA), after taking the fresh weight the leaves samples were oven-dried at $60^{\circ} \mathrm{C}$ for 72 hours and dry weight was recorded.

\section{Nitrate $\left(\mathrm{NO}_{3}^{-}\right)$determination}

Nitrate in leaf tissue was determined by the method of Cataldo et al. (1975). $0.1 \mathrm{~g}$ of leaf disc was boiled for 10 minutes in $5 \mathrm{ml}$ of distilled water. $0.2 \mathrm{ml}$ of salicylic acid was added in $0.05 \mathrm{ml}$ of extract. After incubation at room temperature for 20 minutes, $4.75 \mathrm{ml}$ of $2 \mathrm{~N} \mathrm{NaOH}$ was added to solution. Final volume was made up to $5 \mathrm{ml}$. Absorbance was taken at $410 \mathrm{~nm}$.

\section{Detection of in vivo Nitrate Reductase Activity (NRA)}

NR(EC 1.6.6.6) activity was determined by the method of Silveira et al. (1998). Leaf disc from the second youngest fully expanded leaves (200 $\mathrm{mg}$ fresh mass) were infiltrated twice for two minutes with $5 \mathrm{ml}$ of reaction mixture containing $100 \mathrm{mmol} / \mathrm{l}$ Potassium Phosphate buffer $(\mathrm{pH}$ $7.5)$; $25 \mathrm{mmol} / \mathrm{l} \mathrm{KNO}_{3}$; and $1 \%$ isopropanol. The reaction mixture was incubated at $35^{\circ} \mathrm{C}$ for 30 minutes in the dark. NR activity was estimated from the amount of $\mathrm{NO}_{2}$ formed during the incubation period and released from the leaf discs to the medium after boiling for 5 minutes. Aliquots were mixed with $2 \mathrm{ml}$ of (1:1) $1 \%$ sulfanilamide in $2.4 \mathrm{~mol} / 1 \mathrm{HCl} ; 0.02 \% \mathrm{~N}$-1-naphtyl-ethylenediamine and the absorbance was taken at $540 \mathrm{~nm}$.

\section{Soluble proteins determination}

Soluble protein concentrations were determined using Coomassie brilliant blue (Bradford, 1976) with bovine serum albumin (BSA) as a protein standard.

\footnotetext{
${ }^{*}$ Sea salt solutions for irrigation were prepared by adding required amount of sea salt in tap water per liter. Sea salt is available in crude form in market. About $4 \%$ of its concentration was found equivalent to concentration of salts in the water of Indian Ocean (Castro and Huber, 2005).
} 
174

\section{Statistical analyses}

SPSS version 13 was used for data analysis. Data sets were subjected to two-way analysis of variance (ANOVA). Duncan's multiple range test (DMRT) was used to measure least significant differences (LSD) between treatment methods and controls (Duncan, 1955).

\section{Results and discussion}

Effect of foliar application of $\mathrm{KNO}_{3}$ on vegetative characteristics (leaf area, fresh and dry weight of leaves) of sunflower and safflower plant under different salinity levels is presented in Tab. 1. Leaf area, fresh and dry weight of leaves of both the plants was significantly reduced by the increasing of salinity. In sunflower, leaf area, fresh and dry weight of leaves were reduced by $37.6 \%, 48 \%$ and $51.5 \%$ and in safflower $66.9 \%, 47.3 \%$ and $51.8 \%$ respectively, at the highest salinity level (ECe:9.9dS/m) in comparison with non saline control. Leaf area, fresh and dry weight of leaves of both the plants was substantially increased by foliar spray of potassium nitrate irrespective to the plant growth under non saline or saline conditions. In sunflower, leaf area, fresh and dry weight of leaves were increased by $32 \%, 36.4 \%$, and $43.4 \%$ and in safflower $31.3 \%, 41 \%, 43.1 \%$ respectively at the highest salinity level (ECe:9.9dS/m) in comparison with their respective non sprayed control.

The opposing effects of salinity on the plants growth are a serious problem reported by many workers (Greenway and Munns, 1980; Tester and Davenport, 2003). Ion toxicity and imbalanced nutrition in saline conditions are the main constraints for plant growth. The decline in leaf growth is an earliest response of the plants to salinity (Cramer, 2002; Munns and Termaat, 1986). Both the reduction in leaf growth and increasing of dead leaves at highest salinity level i.e. $0.6 \%$ sea salt solution, led to further reduction in leaf area. This may be caused by ions accumulation in the leaves, particularly old leaves (Greenway and Munns, 1980). Foliar supply of $\mathrm{KNO}_{3}$ to the salt treated plants may reduce toxic ions uptake as well improve $\mathrm{K}$ and $\mathrm{N}$ status of salt treated plants. The role of potassium in ionic balance is reflected in nitrate metabolism (Jeschke and Wolf, 1985). Nitrogen being an active participant of chlorophyll and protein is an essential element for plant growth. Spray with potassium result an increase in leaf potassium content which was accompanied by increased rates of photosynthesis, photorespiration and RuBP carboxylase activity. Hence there was considerable improvement in growth even under saline strata in present investigation. Ebert et al. (2002) found that supplying of $\mathrm{Ca}\left(\mathrm{NO}_{3}\right)_{2}$ at $10 \mathrm{mM}$ had a beneficial effect on growth and metabolism of $\mathrm{NaCl}$ treated guava seedlings. Akram et al. (2009) observed an improvement in growth of sunflower due to the foliar spray of $\mathrm{K}_{2} \mathrm{SO}_{4}$ and $\mathrm{KNO}_{3}$ at $1.25 \%$ under saline concentration of $150 \mathrm{mM} \mathrm{NaCl}$.

The data of leaf ion concentration of both the plants in relation to salinity and $\mathrm{KNO}_{3}$ levels are presented in Fig. 1. Salinity in the root zone led to a significant decrease in $\mathrm{K}$ concentration and an increase in $\mathrm{Na}^{+}$and $\mathrm{Cl}^{-}$concentration. Lacerda et al. (2003) reported high levels of $\mathrm{Na}^{+}$ inhibited the $\mathrm{K}^{+}$concentration in sorghum plants which result an increased $\mathrm{Na}^{+} / \mathrm{K}^{+}$ratio under salt stress. Mohamedin et al. (2006) reported in sunflower that high levels of external $\mathrm{Na}^{+}$interfere with $\mathrm{K}^{+}$acquisition by the roots and disturb the root membranes and alter selectivity. In present investigation foliar application of $\mathrm{KNO}_{3}$ alleviate the toxicity of $\mathrm{Na}^{+}$by decreasing the chances of its accumulation in plant parts. The results of present investigation are in agreement with the findings of many workers in different plant species (Abdel-Rehman, 1999; Cha-um et al., 2010; Sultana et al., 2001; Tabatabaei and Fakhrzad, 2008) who found that nutrients were absorbed by the leaves when applied onto the shoot. Treated leaves contained higher element concentration compared to non sprayed plants even under saline condition.

In present investigation salt stressed resulted an increase in $\mathrm{Cl}^{-}$concentration, about $72 \%$ increase was recorded in leaves of both the plants at the highest salinity

Tab. 1. Effect of foliar application of $\mathrm{KNO}_{3}$ on vegetative characteristics (leaf area, fresh and dry weight of leaves) of sunflower and safflower plant under irrigation of different salinity levels

\begin{tabular}{|c|c|c|c|c|c|c|c|}
\hline \multirow[b]{2}{*}{ Sea salt concentration (\%) } & \multirow[b]{2}{*}{$\begin{array}{l}\text { Foliar spray } \\
\text { treatment }\end{array}$} & \multicolumn{3}{|c|}{ Sunflower } & \multicolumn{3}{|c|}{ Safflower } \\
\hline & & $\begin{array}{c}\text { Leaf area } \\
\text { index }\left(\mathrm{cm}^{2}\right)\end{array}$ & $\begin{array}{c}\text { Leaves fresh } \\
\text { weight }(\mathrm{g})\end{array}$ & $\begin{array}{l}\text { Leaves dry } \\
\text { weight }(\mathrm{g})\end{array}$ & $\begin{array}{c}\text { Leaf area } \\
\text { index }\left(\mathrm{cm}^{2}\right)\end{array}$ & $\begin{array}{c}\text { Leaves fresh } \\
\text { weight }(\mathrm{g})\end{array}$ & $\begin{array}{l}\text { Leaves dry } \\
\text { weight }(\mathrm{g})\end{array}$ \\
\hline \multirow[t]{2}{*}{0 (ECiw:0.5dS/m, ECe:1.8dS/m) } & Control-1(non spray) & $2894.4^{\mathrm{ab}}$ & $65.8^{\mathrm{ab}}$ & $13.9^{\mathrm{ab}}$ & $5065.2^{\mathrm{ab}}$ & $63.6^{\mathrm{ab}}$ & $13.7^{\mathrm{ab}}$ \\
\hline & $\mathrm{KNO}_{3}$ & $3857.0^{\mathrm{a}}$ & $97.5^{\mathrm{a}}$ & $22.6^{a}$ & $6968.0^{\mathrm{a}}$ & $102.8^{\mathrm{a}}$ & $22.2^{\mathrm{a}}$ \\
\hline \multirow[t]{2}{*}{0.3 (ECiw:4.8dS/m, ECe:6.1dS/m) } & Control-2 (non spray) & $2424.4^{\mathrm{ab}}$ & $52.5^{\mathrm{bc}}$ & $10.5^{\mathrm{b}}$ & $3569.8^{b}$ & $50.5^{\mathrm{ab}}$ & $10.2^{\mathrm{b}}$ \\
\hline & $\mathrm{KNO}_{3}$ & $3465.0^{\mathrm{b}}$ & $80.4^{\mathrm{b}}$ & $17.8^{\mathrm{ab}}$ & $5041.8^{\mathrm{ab}}$ & $82.8^{\mathrm{b}}$ & $17.2^{\mathrm{ab}}$ \\
\hline \multirow[t]{2}{*}{0.6 (ECiw:8.6dS/m, ECe:9.9dS/m) } & Control-3 (non spray) & $1806.0^{c}$ & $34.2^{c}$ & $6.74^{c}$ & $1675.0^{c}$ & $33.5^{\mathrm{c}}$ & $6.6^{\mathrm{bc}}$ \\
\hline & $\mathrm{KNO}_{3}$ & $2652.0^{\mathrm{abc}}$ & $53.8^{\mathrm{bc}}$ & $11.9^{\mathrm{bc}}$ & $2438.8^{c}$ & $56.7^{\mathrm{bc}}$ & $11.6^{\mathrm{ac}}$ \\
\hline \multirow[t]{3}{*}{ LSD at level 0.05} & Salt & 16.082 & 1.339 & 0.561 & 15.503 & 1.495 & 0.815 \\
\hline & Spray & 13.131 & 1.094 & 0.458 & 12.658 & 1.221 & 0.666 \\
\hline & $\begin{array}{c}\text { Interaction } \\
\text { (spray x salinity) }\end{array}$ & $* * *$ & $* * *$ & $* * *$ & *** & $* * *$ & ** \\
\hline
\end{tabular}

ECiw, electrical conductivity of irrigation water, ECe, electrical conductivity of soil extract, LSD: Least Significant Difference, ns: not significant, different letters indicate significant differences among treatments at $5 \%$ level of significance in Duncan's Multiple Range Test 
level (i.e. ECe: $9.9 \mathrm{~d} S / \mathrm{m}$ ) in comparison with their non saline control (Fig. 1) and a decrease of $\mathrm{NO}_{3}{ }^{-}$concentration in leaves of both sunflower and safflower plants (Tab. 2). This repression of $\mathrm{NO}_{3}^{-}$was directly proportional to the increasing concentrations of salt. The decrease in $\mathrm{NO}_{3}{ }_{3}^{-}$concentration by salt treatment could be attributed to the disruption of root membrane integrity (Carvajal et al., 1999), an inhibition of nitrate uptake (Parida and Das, 2004) and low $\mathrm{NO}_{3}{ }^{-}$loading into root xylem (Abd-El Baki et al., 2000). The direct competition of chloride with nitrate may also inhibited the uptake of nitrate by nitrate transporters (Deane-Drummond, 1986) or nitrate transporters may be inactivated by the toxic effects of salt ions (Lin et al., 1997) which results higher accumulation of chloride accumulation in leaves. The observed changes in foliar nitrate were negatively correlated with chloride concentration in both sunflower $\left(\mathrm{r}^{2}=0.852, \mathrm{NO}_{3}=-0.219 \times\right.$ [chlorine $\left.]+31.00\right)$ and safflower $\left(\mathrm{r}^{2}+0.864, \mathrm{NO}_{3}=-0.352 \times\right.$ [chlorine] +28.82$)$. The concentration of $\mathrm{Cl}^{-}$was significantly reduced when $\mathrm{KNO}_{3}$ nutrient solution was supplied through foliar spray. This negative relationship between $\mathrm{NO}_{3}{ }^{-}$and $\mathrm{Cl}$ has been previously reported by Kafkafi et al. (1992) and Pearez-Alfocea et al. (1993). Foliarly supplied $\mathrm{NO}_{3}$ through $\mathrm{KNO}_{3}$ decreased $\mathrm{Cl}^{-}$concentration and offset its toxic effects, thereby lessening growth inhibition (Bar $e t$ al., 1997). Tabatabaei et al. (2004) also reported that the decreased of nitrate is accompanied by a high chloride uptake and low rate of xylem exudation in high osmotic condition either by salts or other nutrients. It leads to reduced concentration of nitrate in leaves, consequently reducing NR activity of leaves under salinity conditions.

It appeared from the present results of both sunflower and safflower plant that increasing levels of salinity induced a substantial decline in NRA (Tab. 2). The reduction of
NRA in leaves, under conditions of restricted nitrate flux induced by salt stress, could be due to the enzyme degradation/inactivation and the reduction in gene expression and NR protein synthesis (Ferrario et al., 1998). Ferraio et al. (1998) suggested that the reduction in NR mRNA levels is related to lower levels of $\mathrm{NO}_{3}$ and glutamine in leaves. Salt reduced $\mathrm{NO}_{3}^{-}$fluxes from roots to leaves and impaired the NRA in leaves (Debouba et al., 2007; Foyer et al., 1998). Cramer and Lips (1995) indicated that salinity may control NRA through nitrate uptake since NRA is largely determined by nitrate flux into the metabolic pool. As NR is highly regulated enzyme, its activity being dependent on several internal signals and nitrate is the first signal that induces that transcription of NR genes (Crawford, 1995; Kaiser et al., 2002). Similar reduction under salinity in $\mathrm{NO}_{3}^{-}$and NRA was also reported in leaves of olive trees by Tabatabaei (2006), in tomato by Debouba et al. (2007), in algarrobo by Meloni et al. (2004) and in soybean by Moussa (2004).

Application of foliar mineral, $\mathrm{KNO}_{3}$ significantly increased nitrate content and NR activity in sunflower and safflower plants irrespective to their growth under non saline or saline conditions. The minimizing effects of the activity of nitrate reductase under salinity were offset by foliar application of mineral under various extant in present investigation. The observed changes in foliar NRA induced by both salinity and foliar spray were linearly correlated with the concomitant variation in foliar nitrate content in both sunflower $\left(r^{2}=0.952\right.$, NRA $=0.238+0.364 \times$ [nitrate] $)$ and safflower $\left(r^{2}=0.916, \mathrm{NRA}=0.738+0.204\right.$ $\times$ [nitrate]). Tabatabaei and Fakhrzad (2008) found in perennial ryegrass that 0 to $10 \mathrm{mM} \mathrm{KNO}_{3}$ in the solution applied through soil or foliar increased $\mathrm{NO}_{3}$ concentration in leaves irrespective to plants growth under non saline or saline conditions. Maritinez and Cerda (1989) observed

Tab. 2. Effect of foliar application of KNO3 on amount of nitrate, nitrate reductase activity and soluble proteins of sunflower and safflower plant under irrigation of different salinity levels

\begin{tabular}{|c|c|c|c|c|c|c|c|}
\hline \multirow[b]{2}{*}{$\begin{array}{c}\text { Sea salt } \\
\text { concentration } \\
(\%) \\
\end{array}$} & \multirow[b]{2}{*}{$\begin{array}{l}\text { Foliar spray } \\
\text { treatment }\end{array}$} & \multicolumn{3}{|c|}{ Sunflower } & \multicolumn{3}{|c|}{ Safflower } \\
\hline & & $\begin{array}{c}\text { Nitrate } \\
\mu \text { mole }(\text { g. f.w })^{-1}\end{array}$ & 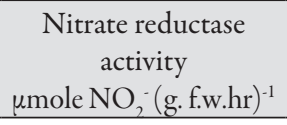 & $\begin{array}{l}\text { Soluble } \\
\text { proteins } \\
\mathrm{mg} / \mathrm{g} \text { f.wt }\end{array}$ & $\begin{array}{c}\text { Nitrate } \\
\mu \text { mole (g. f.w })^{-1}\end{array}$ & $\begin{array}{c}\text { Nitrate reductase } \\
\text { activity } \\
\mu \text { mole } \mathrm{NO}_{2}^{-} \text {(g.f.w.hr) }{ }^{-1}\end{array}$ & $\begin{array}{l}\text { Soluble } \\
\text { proteins } \\
\mathrm{mg} / \mathrm{g} \text { f.wt }\end{array}$ \\
\hline \multirow[t]{2}{*}{$\begin{array}{c}0(\text { ECiw: } 0.5 \mathrm{dS} / \mathrm{m}, \\
\text { ECe: } 1.8 \mathrm{dS} / \mathrm{m})\end{array}$} & $\begin{array}{l}\text { Control-1 } \\
\text { (non spray) }\end{array}$ & $25.6^{\mathrm{ab}}$ & $9.42^{\mathrm{a}}$ & $25.8^{\mathrm{ab}}$ & $24.0^{\mathrm{ab}}$ & $5.45^{\mathrm{ab}}$ & $11.70^{\mathrm{ab}}$ \\
\hline & $\mathrm{KNO}_{3}$ & $29.4^{a}$ & $10.95^{\mathrm{a}}$ & $29.2^{a}$ & $27.1^{\mathrm{a}}$ & $6.30^{\mathrm{a}}$ & $13.26^{a}$ \\
\hline \multirow[t]{2}{*}{$\begin{array}{c}0.3(\text { ECiw: } 4.8 \mathrm{dS} / \mathrm{m}, \\
\text { ECe:6.1dS } / \mathrm{m})\end{array}$} & $\begin{array}{l}\text { Control-2 } \\
\text { (non spray) }\end{array}$ & $23.5^{b}$ & $8.71^{b}$ & $24.0^{\mathrm{ab}}$ & $19.8^{\mathrm{b}}$ & $4.65^{\mathrm{b}}$ & $10.00^{\mathrm{b}}$ \\
\hline & $\mathrm{KNO}_{3}$ & $27.5^{\mathrm{ab}}$ & $10.29^{a b}$ & $27.9^{b}$ & $23.0^{\mathrm{ab}}$ & $5.49^{a b}$ & $11.90^{\mathrm{ab}}$ \\
\hline \multirow[t]{2}{*}{$\begin{array}{c}0.6(\text { ECiw: } 8.6 \mathrm{dS} / \mathrm{m}, \\
\text { ECe:9.9dS } / \mathrm{m})\end{array}$} & $\begin{array}{l}\text { Control-3 } \\
\text { (non spray) }\end{array}$ & $18.7^{\mathrm{c}}$ & $7.10^{c}$ & $19.0^{c}$ & $13.5^{c}$ & $3.48^{c}$ & $7.33^{c}$ \\
\hline & $\mathrm{KNO}_{3}$ & $22.5^{b c}$ & $8.50^{b c}$ & $23.3^{\mathrm{abc}}$ & $15.8^{c}$ & $4.10^{b c}$ & $9.10^{b c}$ \\
\hline \multirow[t]{3}{*}{ LSD at level 0.05} & Salt & 0.544 & 0.328 & 0.179 & 0.436 & 0.297 & 0.174 \\
\hline & Spray & 0.769 & 0.464 & 0.253 & 0.617 & 0.420 & 0.247 \\
\hline & $\begin{array}{c}\text { Interaction } \\
\text { (spray x salinity) }\end{array}$ & ns & ns & * & ns & ns & ns \\
\hline
\end{tabular}

ECiw, electrical conductivity of irrigation water, ECe, electrical conductivity of soil extract, LSD: Least Significant Difference, ns: not significant, different letters indicate significant differences among treatments at $5 \%$ level of significance in Duncan's Multiple Range Test 


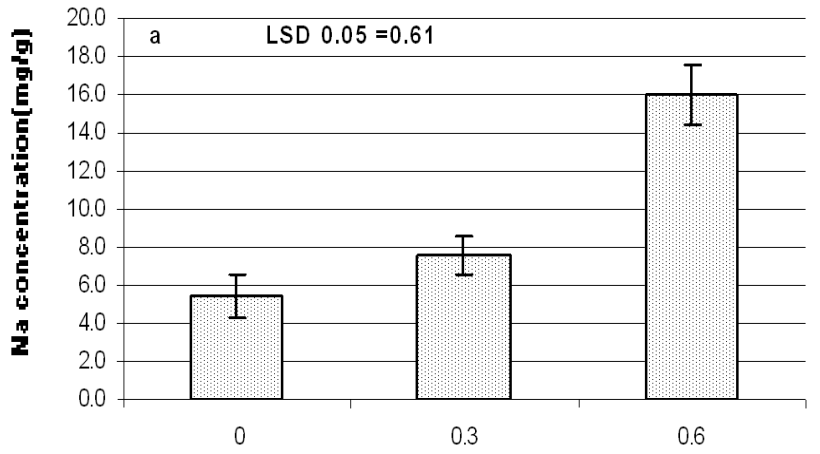

Concentration of sea salt solution (\%)

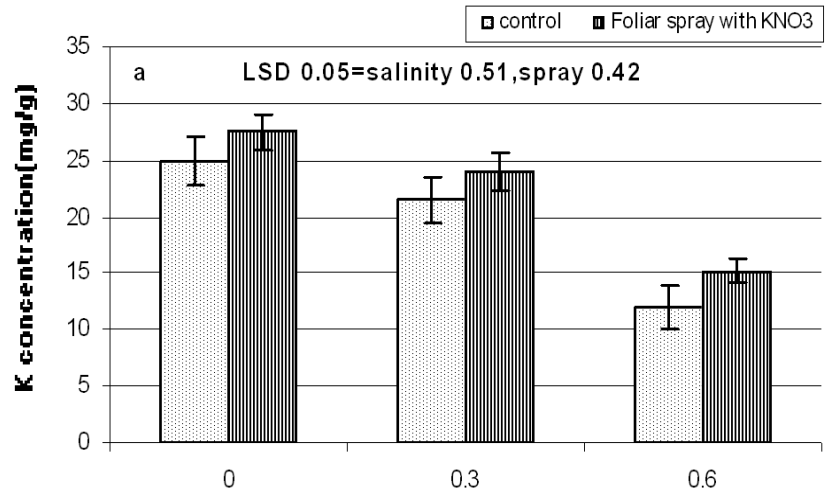

Concentration of sea salt solution( $\%)$

QControl DFoliar spray with KNO3

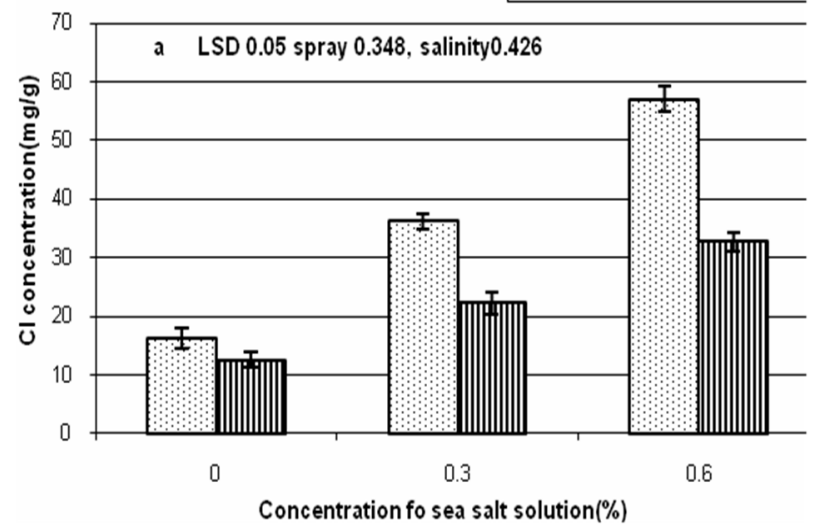

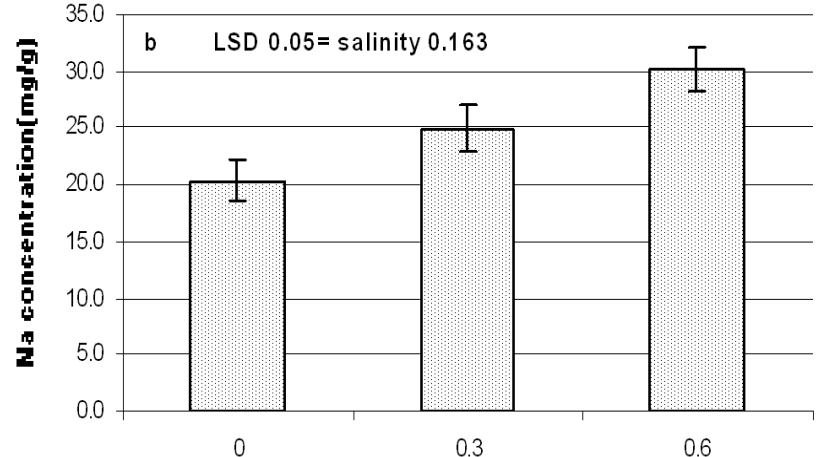

Concentration of sea salt solution (\%)
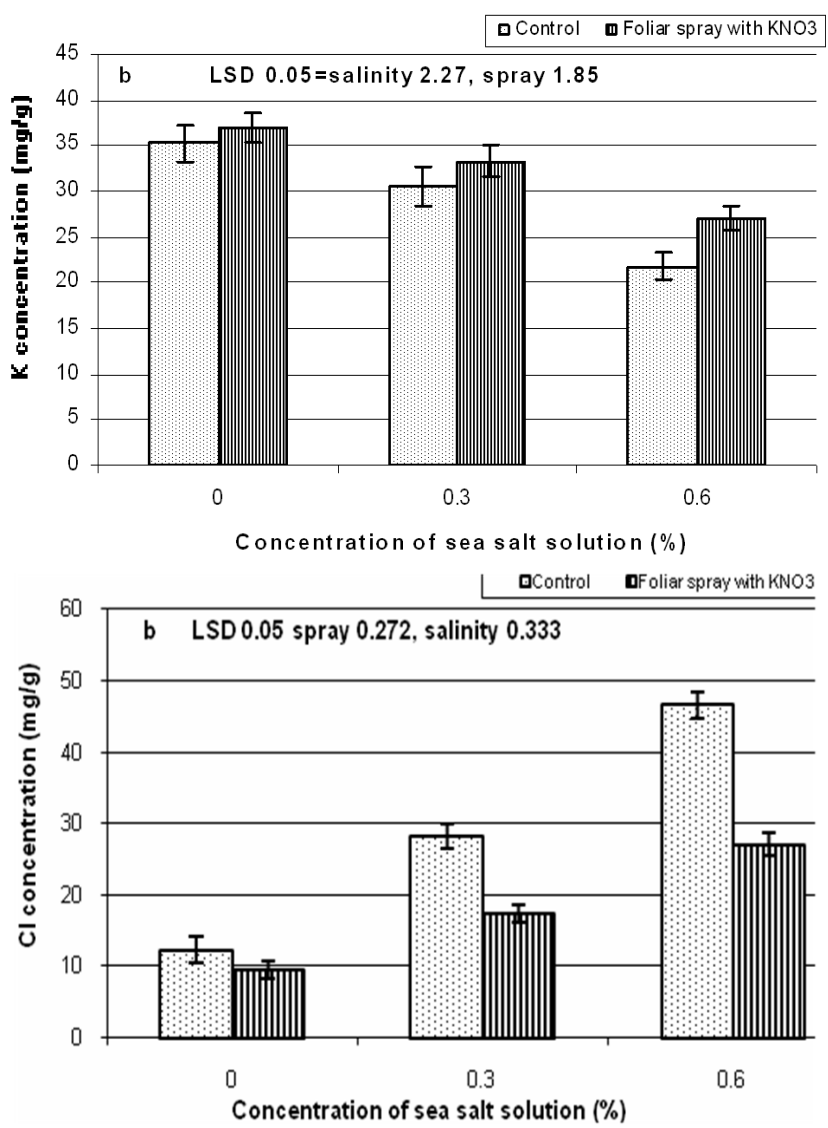

Fig. 1. Effect of salinity and foliar spray of nutrient solution of potassium on $\mathrm{K}$ and $\mathrm{Cl}$ concentration in sunflower (a) and safflower (b) leaves. ECiw: $0.5 \mathrm{dS} / \mathrm{m}$, ECe: $1.8 \mathrm{~d} \mathrm{~S} / \mathrm{m}$ (non saline); ECiw: $4.8 \mathrm{dS} / \mathrm{m}$, ECe: $6.1 \mathrm{dS} / \mathrm{m}$ (0.3\% sea salt solution); ECiw: $8.6 \mathrm{dS} / \mathrm{m}$, ECe: $9.9 \mathrm{dS} / \mathrm{m}$ (0.6\% sea salt solution). Vertical bars mean \pm S.E. $(\mathrm{n}=3)$, LSD: Least Significant Difference; ECiw: electrical conductivity of irrigation water; ECe: electrical conductivity of soil extract

increased NR activity with the exogenous supply of $\mathrm{NO}_{3}$ in tomato and cucumber.

Proteins are generally the products of $\mathrm{NO}_{3}^{-}$assimilation (Barneix and Causin, 1996). The soluble protein concentrations of leaves of sunflower and safflower decreased in salinity as compare to their respective control (Tab. 2) This decrease may be due to the change in the balance between soluble amino acids and proteins by salinity or high salinity may increase break down of protein by proteolytic process. Decrease in protein contents of leaves has been reported in many plants under salt stress irrespective of their salt tolerance (Ashraf and Fatima, 1995; Ahmad and Jabeen, 2009; Moussa, 2004; Parida and Das, 2005). The soluble protein concentrations increased with the foliar application of $\mathrm{KNO}_{3}$ irrespective to the plant growth under non saline or saline conditions. It may be due to the direct involvement of $\mathrm{K}$ in several steps of translation process, including the binding of tRNA to ribosomes (Evans and Wildes, 1971). The exogenous application of $\mathrm{KNO}_{3}$ is related to increased $\mathrm{NO}_{3}^{-}$absorption, its reduction and assimilation (Ruiz and Romero, 1999). 


\section{Conclusions}

The experiments clearly demonstrated the beneficial effects of $\mathrm{KNO}_{3}$ application on growth, nutrients concentration, NRA and soluble proteins of sunflower and safflower plants, irrespective to their growth under non saline or saline conditions.

\section{Acknowledgments}

Provision of funds for this research work by Higher Education Commission (HEC)/Pakistan Academy of Science through a research project are grateful acknowledged.

\section{References}

Abdel-Rahman AAM (1999). Productivity of some rice varieties as influence by different concentrations of foliar spray of urea under saline soil conditions. Egypt J Agric Res 77:242-251.

Abd El-Baki GK, Siefrt ZF, Man HM, Weiner H, Kaldenhoff R, Kaiser WM (2000). Nitrate reductase in Zea mays L. under salinity. Cell Envir 23:515-21.

Ahmad R, Jabeen N (2009). Demonstration of growth improvement in sunflower (Helianthus annuus L.) by the use of organic fertilizers under saline conditions. Pak J Bot 41:1373-1384.

Akram MS, Ashraf M, Akram NA (2009). Effectiveness of potassium sulfate imitigating salt-induced adverse effects on different physio-biochemical attributes in sunflower (Helianthus annuus L.). Flora 204(6):471-483.

Ashraf M, Fatima H (1995). Responses of salt-tolerant and salt sensitive lines of safflower (Carthamus tinctorius L.) to salt stress. Acta Physiol Plant 17(1):61-70.

Azedo-Silva J, Osorio J, Fonseca F, Correia MJ (2004). Effects of soil drying and subsequent re-watering on the activity of nitrate reductase in roots and leaves of Helianthus annuus. Funct Plant Biol 31:611-621

Bar Y, Apelbaum A, Kafkafi U, Goren R (1997). Relationship between chloride and nitrateand its effect on growth and mineral composition of avocado and citrus plants. J Plant Nutr 20:715-731.

Barneix AJ, Causin HF (1996). The central role of amino acids on nitrogen utilization and plant growth. J Plant Physiol 149: 358-362.

Bradford MM (1976). A rapid and sensitive for the quantitation of microgram quantities of protein utilizing the principle of protein-dye binding. Anal Biochem 72:248-254.

Carvajal M, Martnez V, Alcaraz FC (1999). Physiological function of water channels as affected by salinity in roots of paprika pepper. Physiol Plant 105:95-101.

Castro P, Huber ME (2005). Marine Biology, $5^{\text {th }}$ Ed, McGraw Hill Higher Education, New York, 452 p.

Cataldo DA, Haroon M, Schrader TE, Youngs VL (1975). Rapid colorimetricdetermination of nitrate in plants tissue by nitration of salicylic acid. Soil Sci Plant Anal 6(1):71-80.

Chapman HD, Pratt PF (1982). Methods of Analysis for Soils,
Plants and Water; Chapman Publisher: Riverside, CA.

Cha-um S, Siringam K, Juntawong N (2010). Water relations, pigment stabilization, photosynthetic abilities and growth improvement in salt stressed rice plant treated with exogenous potassium nitrate application. Int J Plant Prod 4(3):187-198.

Cornillon P, Palloix A (1997). Influence of sodium chloride on the growth and mineral nutrition of pepper cultivars. J Plant Nutr 20:1085-1094.

Cramer GR (2002). Deferential effects of salinity on leaf elongation kinetics of three grass species. Plant and Soil 253:233-244.

Cramer MD, Lips SH (1995). Enriched rhizophere $\mathrm{CO}_{2}$ concentration can ameliorate the influence of salinity on hydroponically grown tomato plants. Plant Physiol 94:425-433.

Crawford NM (1995). Nitrate: nutrient and signal for plant growth. Plant Cell 7:859-868.

Dean-Drummond CE (1986). A comparison of regulatory effects of chloride on nitrate uptake, and of nitrate on chloride uptake into Pisum sativum seedlings. Physiol Plant 66:115-126.

Debouba M, Maa Roufi-Dghimi H, Suzuki A, Ghorbel MH, Gouia IH (2007). Changes in growth and activity of enzymes involved in nitrate reduction and ammonium assimilation in tomato seedlings in response to $\mathrm{NaCl}$ Stress. Ann Bot 99:1143-1151.

Duncan DB (1955). Multiple range and multiple F test. Biometrics 11:1-42.

Ebert G, Eberle J, Ali-Dinar H, Lüdders P (2002). Ameliorating effects of $\mathrm{Ca}\left(\mathrm{NO}_{3}\right)_{2}$ on growth, mineral uptake and photosynthesis of $\mathrm{NaCl}$-stressed guava seedlings (Psidium guajava L.). Sci Hort 93:125-135.

Evans HJ, Wildes RA (1971). Potassium and its role in enzyme activation. In: Potassium in Biochemistry and Physiology. Proc $8^{\text {th }}$ Colloq Intern Potash Institute.

Ferrario MS, Valadier MH, Foyer C (1998). Over expression of nitrate reductase in tobacco delays drought induced decreases in nitrate reductase activity and mRNA. Plant Physiol 117:293-302.

Flores P, Botella MA, Martínez V, Cerdá A (2002). Response to salinity of tomato seedling with a split-root system: nitrate uptake and reduction. J Plant Nutr 25:177-187.

Foyer CH, Valadier M, Migge A, Beeker TW (1998). Droughtinduced effects on nitrate reductase activity and mRNA and on coordination of nitrogen and carbon in maize plants. Physiol Plant 117:283-292.

Gouia H, Ghorbal MH, Touraine B (1994). Effects of $\mathrm{NaCl}$ on flows of $\mathrm{N}$ and mineral ions and $\mathrm{NO}_{3}$ - reductase rate within whole plants of salt-sensitive bean and salt-tolerant cotton. Plant Physiol 105:1407-1418.

Greenway H, Munns R (1980). Mechanisms of salt tolerance in non halophytes Ann Rev Plant Physiol Mol Biol 31:149-190.

Halperin ST, Gilroy S, Lynch JP (2003). Sodium chloride reduces growth and cytosolic calcium, but does not affect cytosolic $\mathrm{pH}$, in root hairs of Arabidopsis thaliana L. J Exp Bot 54:1269-1280. 
178

Hoagland D, Arnon DI (1938). The water culture method for growing plants without soil. California Agricultural Experiment Station Bulletin 347:1-39.

Huber SC, Bachmann M, Huber JL (1996). Post-translational regulation of NRA: A role for $\mathrm{Ca}^{2+}$ and 14-3-3 proteins. Trends Plant Sci 1(12):432-438.

Jeschke WD, Wolf O (1985). Na dependent net K retranslocation in leaves of Hordeum vulgare cv. 'California Mariout' and Hordeum distichon cv. 'Villa' under salt stress. J Plant Physiol 121:211-223.

Kafkafi U, Siddiqi MY, Ritchie RJ, Glass ADM, Ruth TT (1992). Reduction of nitrate $\left(13 \mathrm{NO}_{3}\right)$ influx and nitrogen $(13 \mathrm{~N})$ translocation by tomato and melon varieties after short exposure to calcium and potassium chloride salts. J Plant Nutr 15:959-975.

Kaiser WM, Weiner H, Kandlbinder A, Tsai CB, Rockel P, Sonoda M, Planchet E (2002). Modulation of nitrate reductase: some new insights, an unusual case and a potentially important side reaction. J Exp Bot 53:875-882.

Kaya C, Higgs D (2003). Suplementary potassium nitrate improves salt tolerance in bell pepper plants. J Plant Nutr 26:1367-1382.

Lacerda CF, Cambraia J, Cano MAO, A RuizH, Prisco JT (2003). Solute accumulation and distribution during shoot and leaf development in two sorghum genotypes under salt stress. Environ Exp Bot 49:107-120.

Lillo C (1994). Light regulation of nitrate reductase in green leaves of higher plants. Physiol Plant 90:616-620.

Lin H, Sandra SS, Schumaker KS (1997). Salt sensitivity and the activities of the H-ATPase in cotton seedlings. Crop Sci $37: 190-197$

Lopez Cantarero I, Ruiz JM, Hernandez J, Romero L (1997). Nitrogen metabolism and yield response to increase in nitrogen-phosphorus fertilization; Improvement in green house cultivation of eggplant (Solanum melongena). J Agric Food Chem 45:4227-4231.

Maritinez V, Cerda A (1989). Nitrate reductase activity in tomato and cucumber leaves as influenced by $\mathrm{NaCl}$ and $\mathrm{N}$ source. J Plant Nutr 12:1335-1350.

Meloni DA, Gulotta MR, Martinez CA, Oliva MA (2004). The effects of salt stress on growth, nitrate reduction, and proline and glycinebetain accumulation in Prosopis alba. Braz J Plant Physiol 16:39-46.

Misra N, Dwiverdi UN (1990). Nitrogen assimilation in germinating Phaseolus aureus under saline stress. J Plant Physiol 135:719-724.

Mohamedin AAM, Abd El-Kader AA, Badran M(2006). Response of sunflower (Helianthus annus L.) plants to salts stress under different water table depths. J Appl Sci 2(12):1175-1184.

Moussa HR (2004). Amelioration of Salinity-Induced Metabolic Changes in Soybean by Weed Exudates. Int J Agri Biol 6(3):499-503.

Munns R, Termaat A(1986). Whole-plant responses to salinity. Aust. J. Plant Physiol 13:143-160.

Naik R, HalepyatiAS, Pujari BT (2007). Effect of organic manures and fertilizer levels on growth, yield components and yield of safflower (Carthamus tinctorius L.). Karnataka J Agric Sci 20(4):835-836.

Nawaz N, Sarwar G, Yousaf M, Naseeb T, Ahmad A, Shah MJ (2003). Yield and yield components of sunflower as affected by various NPK levels. Asian J Plant Sci 2(7):561-562.

Panday S (2000). Iron mediated nitrate reductase activity in different parts of young maize seedlings. Biol Plant 43(1):149-151.

Parida AK, Das AB (2004). Effects of $\mathrm{NaCl}$ stress on nitrogen and phosphorus metabolism in a true mangrove Bruguiera parviflora grown under hydroponic culture. J Plant Physiol 161:921-928.

Parida AK, Das AB (2005). Salt tolerance and salinity effect on plants: a review. Ecotoxicol Environ Saf 60:324-349.

Pearez-Alfocea F, Estan MT, Santa A, Bolarin MC (1993). Effects of salinity on nitrate, total nitrogen, soluble protein and free amino acid levels in tomato plants. J Hort Sci 8:1021-1027.

Rao KR, Gnaham A (1990). Inhibition of nitrate and nitrate reductase activity by salinity stress in Sorghum vulgare. Phytochem 29:1047-1049.

Ruiz JM, Baghour M, Bretones G, Belakir A, Romero L (1998). Nitrogen metabolism in tobacco plants (Nicotiana tabacum L.): Role of Boron as a possible regulatory factor. Int J Plant Sci 159:121-126.

Ruiz JM, Romero L (1999). Nitrogen efficiency and metabolism in grafted melon Plant Sci Hort 81:113-123

Sagi M, Savidov NA, L’Vov NP, Lips SH (1997). Nitrate Reductase and molybdenum cofactor in annual ryegrass as affected by salinity and nitrogen source. Physiol Plant 99:546-553.

Silveira JAG, Matos JCS, Ceccato VM, Sampaio AH, Costa RCL, Viégas RA (1998). Induction of nitrate reductase activity and nitrogen fixation in two Phaseolus species in relation to exogenous nitrate level. Physiol Mol Bio Plants 4:181-188.

Sivasankar S, Oaks A (1996). Nitrate assimilation in higher plants: The effect of metabolites. Plant Physiol Biochem 34:609-620.

Sultana N, Ikeda T, Kashem MA (2001). Effect of foliar spray of nutrient solutions on photosynthesis, dry matter accumulation and yield in sea water-stressed rice. Environ Exp Bot 46:129-140.

Tabatabaei SJ, Gregory P, Hadley P (2004). Uneven distribution of nutrients in the root zone affects the incidence of blossom end rot and concentration of calcium and potassium in fruits of tomato. Plant Soil 258:169-178.

Tabatabaei SJ (2006). Effects of salinity and $\mathrm{N}$ on the growth, photosynthesis and $\mathrm{N}$ status of olive (Olea europaea L.) trees. Sci Hort 108:432-438.

Tabatabaei SJ, Fakhrzad F (2008). Foliar and soil application of potassium nitrate affects the tolerance of salinity and canopy growth of perennial ryegrass (Lolium perenne var 'Boulevard'). Am J Agri Biol Sci 3 (3):544-550.

Tester M, Davenport R (2003). $\mathrm{Na}^{+}$tolerance and $\mathrm{Na}^{+}$transport in higher plants. Ann Bot 91:503-527.

Viegas RA, Barreto de Melo AR, Gomes da Silveira JA (1999). Nitrate reductase activity and proline accumulation in cashew in response to $\mathrm{NaCl}$ salt shock. Rev Bras Fisiol Veg 11:21-28. 